\title{
Identifying and understanding attitudinal diversity on multi-functional changes in woodlands of the Ukrainian Carpathians
}

\author{
Albert Nijnik ${ }^{1}$, Maria Nijnik ${ }^{2, *}$, Serhiy Kopiy ${ }^{3}$, Lyudmyla Zahvoyska ${ }^{3}$, Simo Sarkki ${ }^{4}$, \\ Leonid Kopiy ${ }^{3}$, David Miller ${ }^{2}$
}

${ }^{1}$ Environmental Network Limited, The Hillocks, Tarland, Aboyne AB34 4TJ, Scotland, UK

${ }^{2}$ The James Hutton Institute, Craigiebuckler, Aberdeen AB15 8QH, Scotland, UK

${ }^{3}$ Ukrainian National Forestry University, Gen. Chuprynky 103, Lviv 79057, Ukraine ${ }^{4}$ Thule Institute, PO Box 7300, 90014 University of Oulu, Finland

\begin{abstract}
This paper advances existing knowledge of stakeholder attitudes towards ecosystem-based forest strategies and management practices in marginalized mountain areas of the Ukrainian Carpathians. The principal research question was to analyse the state of affairs regarding multi-functional changes in upland woodlands, as viewed by relevant stakeholders. An ultimate goal was to assist decision-makers in evaluation (e.g. through stakeholder evaluation using the suggested method) and implementation (through stakeholder engagement) of sustainable policy and management decisions. The Q-method, with the sequential application of its correlation and factor analytical tools, was applied to elucidate a range of existing attitudes (e.g. towards the expansion of woodlands under climate change and other drivers) and the spectrum of sustainability (its ecological, economic and social components) to which they relate. Dominant attitudes of representatives of relevant stakeholder groups towards multi-functional changes in forestry in the Carpathian Mountains were revealed and analysed. Key factors influencing the attitudinal diversity were explained. The results improve our understanding of stakeholder priorities and of commonalities and differences in existing attitudes/perceptions, providing some indication of how the diversity of attitudes towards forestry changes (e.g. integration of woodlands in mountain landscapes) could potentially influence sustainable forestry decisions. At times, entirely opposite attitudes (e.g. of the so-called Conservationists and Productivists attitudinal groups) towards forestry practices and key objectives of forestry in the Carpathian uplands were revealed. However, people put strong emphasis on multi-functional forestry offering a range of benefits to people, the environment and the economy.
\end{abstract}

KEY WORDS: Public attitudes and preferences - Ecosystem-based adaptation practices · Carpathian Mountains · Q-method

\section{INTRODUCTION}

International, regional and national environmental policies are drivers of changes in European mountains. Globalization processes, technological and economic advances, social innovations, and environmental and climatic changes also influence the de-

${ }^{*}$ Corresponding author: maria.nijnik@hutton.ac.uk

${ }^{\S}$ Advance View was available online May 18, 2017 velopment of mountain regions. Specifically, the Paris Agreement-negotiated at the 21st Conference of the parties (COP) of the UNFCCC and adopted on 12 December 2015 (European Commission 2015) recognized the role of non-party stakeholders in addressing climate change through the up-scaling of efforts and support actions to reduce carbon emis-

(C) The authors 2017. Open Access under Creative Commons by Attribution Licence. Use, distribution and reproduction are unrestricted. Authors and original publication must be credited.

Publisher: Inter-Research · www.int-res.com 
sions, build resilience and decrease vulnerability to the adverse effects of climate change. At the Third Meeting of the Conference of the Parties to the Framework Convention on the Protection and Sustainable Development of the Carpathian Mountains (Bratislava, 25-27 May 2011), environment ministers and experts from Central and Eastern Europe discussed the drivers and responses to manifold changes affecting the region, and adopted a protocol on sustainable forest management. Identification of areas with high conservation value, and the establishment and better management of an ecological network under Natura 2000 predefined a key policy issue in the Carpathian Mountains, which are considered to be 'a unique natural treasure of great beauty and ecological value, an important reservoir of biodiversity, the headwaters of major rivers, an essential habitat and refuge for many endangered species...' (The Carpathian Convention 2003).

Ukraine signed the Carpathian Convention accepting the strategy of sustainable development of this region. It foresees that the level of production in forestry and its specialization are to match the natural resource regeneration potential. Additional measures that stipulate the environmental role of forests were added to The Forest Code of Ukraine (2006). However, adopting the sustainable development considerations in a country in transition to a market economy, such as Ukraine, requires adjustment of the complexity of institutions to the requirements of a market economy (Krott 2008). It also requires the promotion of involvement of local communities in decision-making and policy implementation (Nijnik et al. 2009a).

However, 'implementation deficits' (common to young democracies) demonstrate a gap between the formulation of policy goals and their implementation (Krott 2008, Keeton \& Crow 2009). These include the following: lack of will of policy actors; a shortage of skilled experts (e.g. trained for tackling climate change challenges); misperceptions of the policy targets, measures and instruments by local stakeholders (Zahvoyska et al. 2014); a deficit of resources (especially financial); weak market infrastructure (tenure rights on land and forest resources are not properly ensured and enforced; market failures are common; Nijnik \& Oskam 2004; Soloviy et al. 2012); and, particularly observed in remote mountain areas, deficient democratic institutions and therefore an incomplete participation process (Bizikova et al. 2012, Sarkki et al. 2016).

In this context, social innovation (www.simra-h2020. eu) is considered to be pivotal. While aiming at improv- ing human wellbeing, it responds to fresh changes in society and to pressing social demands that are traditionally not addressed by existing institutions. Social innovation manifests itself in new institutions, related relationships, networks, interactions and collaborations between people. It promotes the development and uptake of new services and new fields of activity, such as social entrepreneurship and social enterprises (i.e. businesses trading for social purposes within the social economy, which also includes foundations, charities and cooperatives that improve the quality of life of individuals and communities). Examples are communityowned renewable energy inititatives, and social enterprises which help disadvantaged groups gain access to work as well as to healthcare. Social innovation in the Ukrainian Carpathians may also respond to the new structural disadvantages that marginalised rural areas have seen in the frame of rising agglomeration economies resulting from globalisation.

However, boosting social innovations and linked governance mechanisms is difficult in marginalized rural areas. This is particularly challenging in the Ukrainian Carpathians, where the observed deficiency of stakeholder knowledge and capacity in the climatechanged and carbon-constrained world (Elbakidze \& Angelstam 2013, Krynytskyy \& Chernyavskyy 2014) is multiplied by 'path dependency' (on the former, i.e. command-and-control economy), and the legacy of 'politonomy' (the nexus between economic agents and politicians) in this country (Nijnik \& Oskam 2004).

Forestry in the Ukrainian Carpathians remains regimented. Practically all forests are publicly owned and managed by the state based on centralized planning at the ministerial level (Soloviy et al. 2012). However, the presence of 'black' and 'grey' timber markets (i.e. different degrees of tax avoidence in a 'shadow' economy) implies the absence of governance frameworks necessary to warrant sustainable forestry development (Krott 2008). The detected mismatches between national, regional and local policies, and existing gaps between multi-functional forest policy goals and the state of affairs on the ground, contribute to the challenges (Soloviy 2010).

Stakeholders in multi-functional forestry are communities of place (e.g. forest owners, users and local people) and wider communities of interest (e.g. governments and authorities, non-governmental organizations). Priorities of these stakeholder groups may substantially differ (Nijnik \& Miller 2014). Further, notions of sustainable provision of ecosystem services become even more subjective when viewed from the perspectives and goals of an individual. Therefore, complexity, multiplicity and at times the uncer- 
tainty related to simultaneous production of multiple forest ecosystem services to be delivered to their multiple, and at times very diverse, beneficiaries may result in conflicts of stakeholder interests, and it is important to reduce and/or resolve possible conflicts (Vogel \& Lowham 2007).

A way forward could be to use new methods to engage with stakeholders and develop a better understanding of their perspectives of land use changes and their requirements, expectations and aspirations, and the role of woodlands in such perspectives (Prell et al. 2009). A deeper understanding of stakeholder perceptions is essential (Zahvoyska et al. 2015). It is needed, for example, for linking forest management practices (including carbon forestry) to biodiversity conservation requirements influencing policy design in forests that are managed for multiple purposes. Stakeholder engagement is becoming an instrument for targeting sustainability in multi-functional forestry where the trade-offs between forest ecosystem services are a matter of concern.

Current literature on stakeholder attitudes to multi-functional mountain forest policy and management is limited (Sarkki et al. 2016). However, stakeholder engagement can be considered part of adaptive innovative governance, where decision-making is based on learning from past experiences and where stakeholder evaluation is a basis for capacity building and participatory decision-making (MuñozRojas et al. 2015). These ideas come close to those of adaptive co-management, which implies learning from past experiences, being flexible to changes, using science to reflect governance, and co-constructing knowledge with stakeholders (Berkes 2009). Capacity and trust building, knowledge sharing and learning-by-doing, strengthening of science-society-policy relationships, and boosting social innovation are considered essential in this regard (Funtowicz \& Ravetz 1993, Nijnik \& Oskam 2004). An improved understanding of stakeholder attitudes and perceptions could be seen as a first step in getting manifold actors engaged in the decision-making.

Thus, our main purpose in this paper is to examine the heterogeneity of stakeholder attitudes towards multi-functional changes in upland woodlands of the Ukrainian Carpathians. We examine the attitudinal diversity concerning the services that forest ecosystems can provide and the trade-offs between these services. We map similarities and divergences in stakeholder attitudes towards ecosystem-based forest policy and management decisions in upland woodlands of the Carpathian region in the belief that this research could be particularly useful in identify- ing potential conflicts (e.g. caused by differing stakeholder interests) so as to avoid and/or manage them, or for assisting relevant decision-makers with the incorporation of public perceptions into policy design. Considerations around the forest policy and management, decision-making and governance in the region form the key focus of this paper, while we seek to advance the knowledge of ecosystem-based adaptation practices in the Carpathian uplands, as seen through the eyes of people on the ground.

The Methods section briefly presents the Q-method applied. In the Results section, key outputs of quantitative analyses are interpreted as social discourses in order to construct the typologies of experts' perspectives on adaptation policy and practices in the Ukrainian Carpathians. Further, we explain the attitudinal heterogeneity from contextual and personal factors, and proceed with a brief Discussion section. Findings show a broad discourse of stakeholder perspectives. This diversity was identified and examined to help respond to existing challenges, including climate change, with an ultimate aim of devising betterinformed and more sustainable ecosystem-based forest policy and management decisions. Finally, conclusions are drawn to capitalize on the methods used and our key findings.

\section{METHODS}

The Q-method is a participatory, systematic and rigorous scientific tool (Stephenson 1963) designed to reveal and examine existing attitudes and perspectives, provide in-depth insights into attitudinal diversity and human preferences, identify the key criteria concerning the issues in question that are important to people, and to explain major factors influencing the heterogeneity of stakeholder attitudes and perspectives (Watts \& Stenner 2012).

The Q-method (Schmolck 2012) combines qualitative and quantitative tools (Brown 1996). It incorporates elements of behavioural studies into action research (Miller et al. 2009, Nijnik et al. 2014) and can be viewed as a quantitative method for doing discourse analysis (van Exel \& De Graaf 2005). Unlike the better-known R-method used in surveys, the Qmethod enables researchers to discover similarities and differences across the attitudes and perceptions of individuals (rather than among traits) by sorting the statements.

Statements on the issue in question are derived through a concourse analysis, i.e. from interviews or written narratives, and can comprise discourses and 
media, encompassing considerations spoken and written (Davies et al. 2005). Commonly, statements emerge from interviews and communication with stakeholders. However, they can be derived from secondary sources (McKeown \& Thomas 2013, Stevenson 2015). Then, in order to examine individual opinions on specific issues presented in statements and assess these statements in relation to each other, respondents are asked to sort statements according to the level of agreement/disagreement in a fixed, normally distributed scale, which is commonly used in this type of research (Watts \& Stenner 2012).

The sorting exercise results in Q-sorts. Each Q-sort, which is the formal model of each respondent's attitude to the statements, is then correlated with every other Q-sort, and their inter-correlation matrix is factoranalysed (e.g. using principal component analysis [PCA] and Varimax rotation). This leads to attitudinal clusters (Brown 1996) and to linking these clusters to individual characteristics of respondents (Nijnik et al. 2014). However, the most important outcome is that the identified factors permit the capture of the variety of individual attitudes and permit the structuring of them in such a way that different 'common discourses' emerge (Stevenson 2015). The resulting factor arrays, i.e. typical Q-sorts, represent the attitudes people have, enabling researchers to describe and improve their understanding of the attitudinal heterogeneity (Nijnik et al. 2010, McKeown \& Thomas 2013, Nijnik et al. 2014).

The Q-method allows for a rather simple data set because most of the data derive from how much information is implicit in each participant's Qsort, i.e. the formal model of each individual's understanding of the points of view at issue (Barry \& Proops 1999). The Q-method is useful for examining the areas of consensus and conflict between people, and for specifying, selecting and evaluating policy options (Nijnik et al. 2016). However, it does not allow for the extrapolation of results (McKeown \& Thomas 2013).

To better match the research objectives and be time- and resource-efficient, for this study we decided to draw on existing material (i.e. secondary sources). Rigorous and extensive data collection was conducted.

Table 1. Distinguishing statements for Group 1 (Conservationists). In Tables 1 to 5 , the rank is derived from the weighted composites, where ${ }^{*} p<0.01$

\begin{tabular}{|c|c|c|c|}
\hline No. & Statement & Rank & Score \\
\hline 1 & $\begin{array}{l}\text { Woodlands are an important part of our national heritage } \\
\text { and should be preserved whatever the cost }\end{array}$ & 4 & $2.17^{*}$ \\
\hline 12 & $\begin{array}{l}\text { The rights of people to enjoy the beauty of treeline areas are } \\
\text { more important than making profits from the land }\end{array}$ & 2 & $1.07^{*}$ \\
\hline 6 & $\begin{array}{l}\text { I support woodland expansion in treeline areas for multiple } \\
\text { purposes }\end{array}$ & 1 & $0.34^{*}$ \\
\hline 11 & $\begin{array}{l}\text { Woodlands should be planted if they improve visual beauty } \\
\text { of the landscape }\end{array}$ & 0 & $-0.17^{*}$ \\
\hline 25 & $\begin{array}{l}\text { Shortage of investment is the main challenge in treeline } \\
\text { areas }\end{array}$ & 0 & $-0.22^{*}$ \\
\hline 9 & $\begin{array}{l}\text { Forest where trees are planted very close together is } \\
\text { unacceptable for wildlife and should be cut down }\end{array}$ & -2 & $-0.89^{*}$ \\
\hline 23 & $\begin{array}{l}\text { Woodland expansion in treeline areas to create jobs is more } \\
\text { important than protecting nature }\end{array}$ & -3 & $-1.18^{*}$ \\
\hline 14 & $\begin{array}{l}\text { It should be possible to cut the trees down, if the land is } \\
\text { needed for other purposes }\end{array}$ & -3 & $-1.20^{*}$ \\
\hline 20 & $\begin{array}{l}\text { The currently wooded areas could be made wealthy through } \\
\text { clear-cutting }\end{array}$ & -4 & $-1.79^{*}$ \\
\hline
\end{tabular}

Table 2. Distinguishing statements for Group 2 (Productivists)

\begin{tabular}{|c|c|c|c|}
\hline No. & Statement & Rank & Score \\
\hline 25 & Shortage of investment is the main challenge in treeline areas & 4 & $2.19^{*}$ \\
\hline 16 & Planting forests to produce timber should be a policy priority & 3 & $2.03^{*}$ \\
\hline 22 & $\begin{array}{l}\text { Creation of forest is to be promoted as this provides employ- } \\
\text { ment opportunities for remote rural communities }\end{array}$ & 3 & $0.98^{*}$ \\
\hline 18 & $\begin{array}{l}\text { Letting wildlife take care of itself should be a principle of } \\
\text { forest management }\end{array}$ & 2 & $0.94^{*}$ \\
\hline 24 & Forest management in the uplands should be profitable & 2 & $0.69^{*}$ \\
\hline 8 & $\begin{array}{l}\text { We should only harvest forests in treeline areas within } \\
\text { ecological limits }\end{array}$ & 1 & $0.44^{*}$ \\
\hline 1 & $\begin{array}{l}\text { Woodlands are an important part of our natural heritage and } \\
\text { should be preserved whatever the cost }\end{array}$ & 0 & $0.29^{*}$ \\
\hline 3 & $\begin{array}{l}\text { We should expand woodlands today to make sure that future } \\
\text { generations have plenty of timber }\end{array}$ & -1 & $-0.29^{*}$ \\
\hline 10 & $\begin{array}{l}\text { I support the creation of new woodlands, but any new } \\
\text { planting must be in tune with the character of the landscape }\end{array}$ & -1 & $-0.63^{*}$ \\
\hline 12 & $\begin{array}{l}\text { The rights of people to enjoy the beauty of treeline areas are } \\
\text { more important than making profits from the land }\end{array}$ & -2 & $-1.23^{*}$ \\
\hline 6 & $\begin{array}{l}\text { I support woodland expansion in treeline areas for multiple } \\
\text { purposes }\end{array}$ & -3 & $-1.37^{*}$ \\
\hline 7 & Public access should be given to all forests & -4 & $-1.89^{*}$ \\
\hline
\end{tabular}


Table 3. Distinguishing statements for Group 3 (Non-Green Technocrats)

\begin{tabular}{|c|c|c|c|}
\hline No. & Statement & Rank & Score \\
\hline 25 & Shortage of investment is the main challenge in treeline areas & 2 & $1.09^{*}$ \\
\hline 16 & Planting forests to produce timber should be a policy priority & 2 & $1.20^{*}$ \\
\hline 18 & $\begin{array}{l}\text { Letting wildlife take care of itself should be principle of forest } \\
\text { management }\end{array}$ & -1 & $0.80^{*}$ \\
\hline 13 & $\begin{array}{l}\text { I support government policies of woodland expansion be- } \\
\text { cause woodlands improve the landscape and attract tourists }\end{array}$ & -2 & $-1.11^{*}$ \\
\hline 12 & $\begin{array}{l}\text { The rights of people to enjoy the beauty of treeline areas are } \\
\text { more important than making profits from the land }\end{array}$ & -4 & $-2.05^{*}$ \\
\hline
\end{tabular}

Table 4. Distinguishing statements for Group 4 (Challengers)

\begin{tabular}{|c|c|c|c|}
\hline No. & Statement & Rank & Score \\
\hline 16 & Planting forests to produce timber should be a policy priority & 4 & $2.58^{*}$ \\
\hline 12 & $\begin{array}{l}\text { The rights of people to enjoy the beauty of treeline areas are } \\
\text { more important than making profits from the land }\end{array}$ & 3 & $1.08^{*}$ \\
\hline 23 & $\begin{array}{l}\text { Woodland expansion in treeline areas to create jobs is more } \\
\text { important than protecting nature }\end{array}$ & 0 & $-0.14^{*}$ \\
\hline 14 & $\begin{array}{l}\text { It should be possible to cut the trees down, if the land is } \\
\text { needed for other purposes }\end{array}$ & -1 & $-0.64^{*}$ \\
\hline 6 & $\begin{array}{l}\text { I support woodland expansion in treeline areas for multiple } \\
\text { purposes }\end{array}$ & -2 & $-0.69^{*}$ \\
\hline 25 & Shortage of investment is the main challenge in treeline areas & -2 & $-1.25^{*}$ \\
\hline 18 & $\begin{array}{l}\text { Letting wildlife take care of itself should be a principle of } \\
\text { forest management }\end{array}$ & -3 & $-1.38^{*}$ \\
\hline
\end{tabular}

Table 5. Distinguishing statements for Group 5 (Green Protectionists)

\begin{tabular}{|c|c|c|c|}
\hline No. & Statement & Rank & Score \\
\hline 9 & $\begin{array}{l}\text { Forest where trees are planted very close together is } \\
\text { unacceptable for wildlife and should be cut down }\end{array}$ & 4 & $1.71^{*}$ \\
\hline 6 & $\begin{array}{l}\text { I support woodland expansion in treeline areas for multiple } \\
\text { purposes }\end{array}$ & 2 & $1.33^{*}$ \\
\hline 25 & $\begin{array}{l}\text { Shortage of investment is the main challenge in treeline } \\
\text { areas }\end{array}$ & 2 & $1.18^{*}$ \\
\hline 12 & $\begin{array}{l}\text { The rights of people to enjoy the beauty of treeline areas are } \\
\text { more important than making profits from the land }\end{array}$ & 1 & $0.49^{*}$ \\
\hline 24 & Forest management in the uplands should be profitable & 0 & $-0.13^{*}$ \\
\hline 23 & $\begin{array}{l}\text { Woodland expansion in treeline areas to create jobs is more } \\
\text { important than protecting nature }\end{array}$ & -2 & $-0.99^{*}$ \\
\hline 14 & $\begin{array}{l}\text { It should be possible to cut the trees down, if the land is } \\
\text { needed for other purposes }\end{array}$ & -4 & $-2.17^{*}$ \\
\hline
\end{tabular}

in Tables 1 to 5) reflect stakeholder needs in the Carpathians, as these are linked to the ecosystems and their services (e.g. 'Woodlands are an important part of our national heritage', or 'Woodlands should be planted, if they improve visual beauty of the landscape'); forest policy (e.g. 'Planting more forests to produce timber should be a policy priority') and adaptation strategy (e.g. 'I support woodland expansion for multiple purposes', or 'We should only harvestforests within ecological limits'); forest management (e.g. 'Forest management should be profitable'); decision-making processes in forestry (e.g. 'It should be possible to cut the trees down, if the land is needed...'); and policy measures and governance (e.g. 'Shortage of investment is the main challenge in treeline areas'). We came up with 25 statements and, correspondingly, 25 boxes in the Q-sort chart (Fig. 1).

After pre-testing and improving the statements with colleagues from the Earth System Science and Environmental Management (ESSEM) European Cooperation in Science and Technology (COST) Action ES1203, Enhancing the Resilience Capacity of Sensitive Mountain Forest Ecosystem under Environmental Change (SENSFOR), the set of statements was finalized and presented to respondents, i.e.

For this purpose, we used available research results (e.g. surveys in the form of reports, blogs, etc.) and relevant literature sources, including Ukrainian ones that addressed forest policy and governance, multifunctional forestry, decision-making, and sciencesociety relationships in particular (Nijnik et al. 2009b, Sarkki \& Karjalainen 2012, Soloviy et al. 2012, Sarkki et al. 2016). A set of Q-statements reflecting different sub-elements of the issue in question was designed. The statements (somewhat shortened, with examples people living and working in the Carpathian Mountains. Respondents were identified, following van Asselt et al. (2001), who distinguished 5 types of participant considering public decisions: (1) government/ decision-makers; (2) citizens; (3) interest groups; (4) business-people; and (5) scientific experts. Forty respondents, selected to be as diverse as possible in their social, economic, political and educational backgrounds, performed the Q-sorting. They were approximately equally distributed among the 5 types 


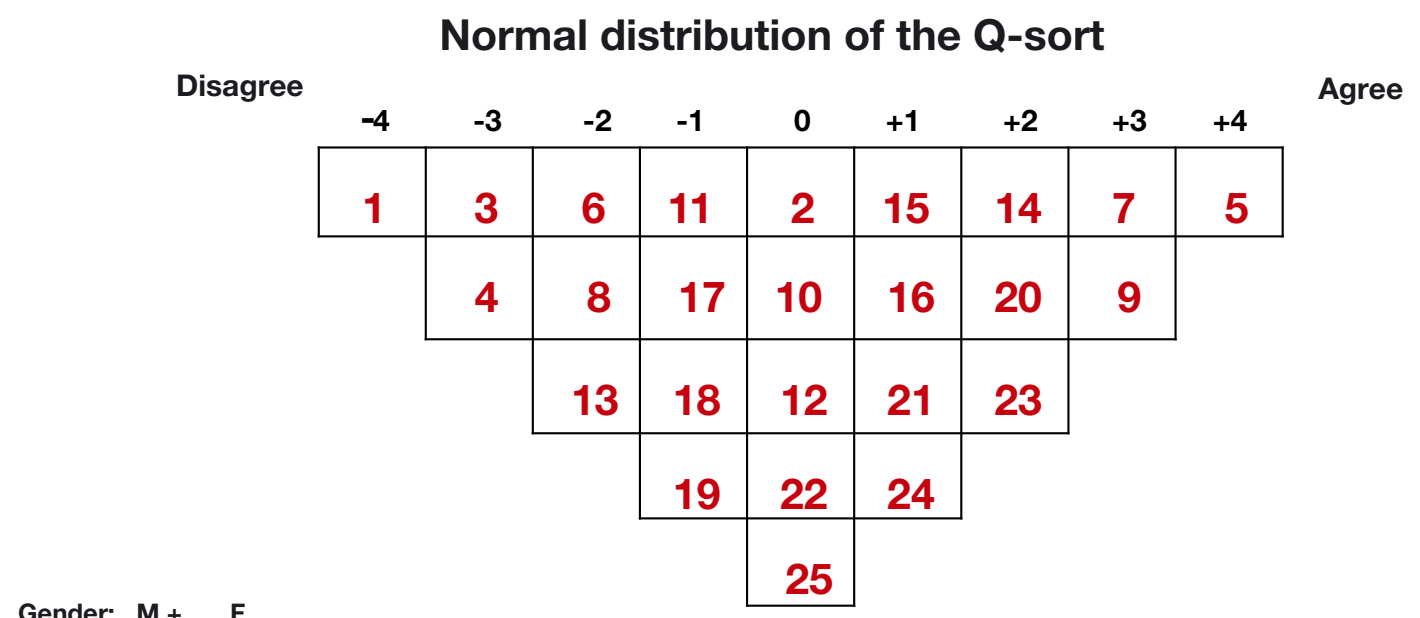

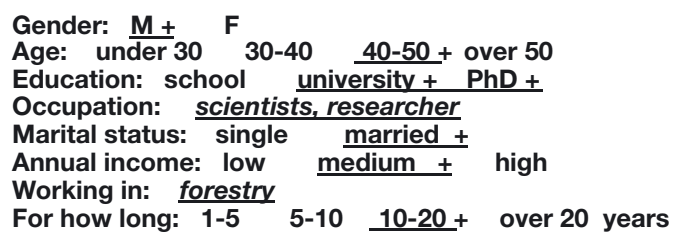

identified by van Asselt et al. (2001), with local people representing 'citizens', but only 6 respondents representing 'business people'.

We translated the questionnaire into Ukrainian and approached the selected respondents in person, initially explaining the purpose of this research, briefly presenting its method and providing information about this study. Each respondent was asked to distribute the statements across boxes in the score sheet according to his/her agreement/disagreement to each one and his/her assessment of the statements in relation to each other. Respondents therefore ranked statements on the scale ranging from +4 to -4 , where +4 indicated full agreement and -4 full disagreement with the statement, and 0 indicated a neutral attitude to it (but could also mean 'ambivalent', or 'don't know', depending on the respondent) (Fig. 1).

The output data were assessed using the sequential application of correlation and factor analyses (i.e. PCA and Varimax rotation). Correlation analysis was used to compare the views among respondents, while PCA was used to categorize correlated expert views under different 'factors' by creating new uncorrelated choice variables that captured the common essence of the individual Q-sorts (Brown 1980, Brown 1996, Nijnik et al. 2013). This approach ultimately enabled us to identify the prevailing attitudinal typologies and compare the key differences and similarities between the identified groups of attitudes.

Additionally, and fully complying with the requirements stipulated by scientific ethics (i.e. without disclosing any personal information), we asked respondents about gender, age, work experience, edu-
Fig. 1. Example of a Q-sort completed by a participant. The number in each box represents the statement number. The position of each statement in the Q-sort chart indicates the participant's agreement/disagreement with each of the 25 statements and his/her judgement on the statements in relation to each other

cation, occupation, income level, partnership status and number of children. Finally, we provided an interpretation of the social discourses uncovered by the quantitative analysis, contrasted the value outputs with the above-named socio-economic characteristics of respondents, verified our results with respondents, and communicated the final results to them and a wider audience, i.e. at the SENSFOR meeting of October 2015, through a press release (in Ukrainian) and through this paper.

\section{RESULTS}

The modelling outputs received through factor extraction (PCA), Varimax rotation and interpretation demonstrated that 4 factors (with correlations ranging from -0.20 to 0.37 ) provide the best representation of distinctive types of existing attitude, or discourse. Approximately $50 \%$ of respondents are uniquely associated with one of the factors (for which they have their only significant factor loading). However, almost $50 \%$ of respondents are mixtures of 2 or more types. The number of factors is, therefore, not totally deterministic - not every individual is a member of only one factor (i.e. attitudinal group). It also means that we have purely loading Qsorts and confounding Q-sorts. However, our 5 factors cumulatively captured $69 \%$ of the total variance (i.e. the full meaning and variability within the data). The values of variance (\% expl.Var) in the total dataset of individual Q-sorts, as explained by the factors, are $42,9,7,6$ and 5, respectively. 


\section{Characterization of the identified attitudinal groups}

Based on a series of output tables, the distinguishing statements (playing the principal role in identifying the attitudinal groups) were analysed for each factor to better understand the substance of the prevailing attitudinal groups (Tables 1 to 5). All statements concern the Carpathian upland areas, but this context is omitted to save space.

Group 1 respondents (Conservationists) believe that ' woodlands are an important part of the heritage and should be preserved whatever the cost' (derived Q-method value: +4 ) with the assurance that 'the rights of people to enjoy the beauty of treeline areas are more important than making profits from the land' (+2). These experts support 'woodland expansion for multiple purposes' (+1) (Table 1). They reject 'tree-felling in the Carpathian uplands' (-3), especially 'clear-cutting' (-4). These respondents are not supportive of the 'creation of jobs at the expense of endangering wildlife' (-3) or the 'increase in timber production' (-2). They voted for the 'preservation of woodlands' and seem not to be interested in an increase in 'investment'.

Group 2 respondents (Productivists) believe that 'shortage of investment is the main challenge in treeline areas' $(+4)$. They strongly 'support planting trees for timber production' (+3) rather than 'woodland expansion for multiple purposes' (-3). They support woodlands expansion 'to provide employment opportunities' (+3) and agree that 'forest management should be profitable' $(+2)$. They rated 'beauty of landscapes' (-2) and 'planting of more trees for the sake of future generations' (-1) fairly low (Table 2 ).

Group 3 respondents (Non-Green Technocrats) experts believe that 'shortage of investment is the main challenge' (+2) and that woodlands expansion 'to create jobs is more important than protecting wildlife and nature' (+2). These respondents, labelled as NonGreen Technocrats, support woodland expansion 'for timber production' (+2) but not 'for multiple purposes' $(-1)$ or 'to improve the landscape and attract tourists' to remote areas $(-2)$ (Table 3$)$.

Group 4 respondents (Challengers) express thoughtprovoking attitudes to forest management in upland areas. They consider that 'planting forests to produce timber should be a policy priority' $(+4)$. However, at the same time, they support 'the rights of people to enjoy the beauty of treeline areas, which they consider to be more important than making profits from the land' (+3). They are against poorly justified felling 'of trees' (-1), but also against expansion of woodlands 'for multiple purposes' (-2). Through their attitudes, Challengers seem to strive for reaching a balance between managing and using woodlands for timber, in upland woodlands, with their promotion of wider ecosystem services considerations (Table 4).

Group 5 respondents (Green Protectionists) consider 'that forests where trees are planted very close together are unacceptable for wildlife' $(+4)$. They support expansion of woodlands 'for multiple purposes' $(+2)$. They also think that shortage of 'investment is the challenge in treeline areas' $(+2)$ and suggest 'that rights of people to enjoy the beauty of treeline areas are more important than making profits from the land' $(+1)$. These respondents reject any felling of trees in the Carpathian uplands (-4), as well as the planting of forest either for timber production $(-3)$, or to create jobs $(-2)$. They have no clear opinion of whether profitability in forestry is desirable, or whether or not the wildlife should take care of itself (Table 5).

Research also identified social-economic background characteristics of respondents across the atti-

Table 6. Social-economic characteristics of respondents across the identified attitudinal groups

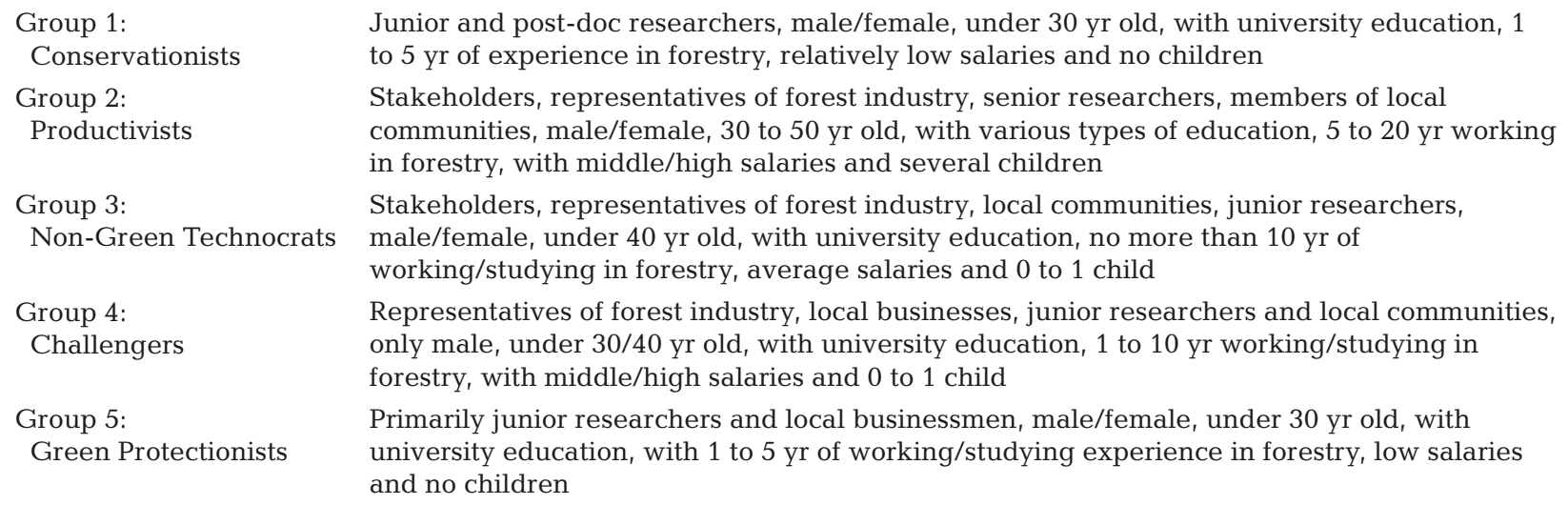

Junior and post-doc researchers, male/female, under $30 \mathrm{yr}$ old, with university education, 1 to $5 \mathrm{yr}$ of experience in forestry, relatively low salaries and no children

Stakeholders, representatives of forest industry, senior researchers, members of local communities, male/female, 30 to $50 \mathrm{yr}$ old, with various types of education, 5 to $20 \mathrm{yr}$ working in forestry, with middle/high salaries and several children

Stakeholders, representatives of forest industry, local communities, junior researchers, male/female, under $40 \mathrm{yr}$ old, with university education, no more than $10 \mathrm{yr}$ of working/studying in forestry, average salaries and 0 to 1 child

Representatives of forest industry, local businesses, junior researchers and local communities, only male, under 30/40 yr old, with university education, 1 to 10 yr working/studying in forestry, with middle/high salaries and 0 to 1 child

Primarily junior researchers and local businessmen, male/female, under 30 yr old, with university education, with 1 to $5 \mathrm{yr}$ of working/studying experience in forestry, low salaries and no children 
tudinal groups (Table 6). The discourse appeared to be somewhat influenced by occupation, education, age and gender of respondents. For example, the observation that Group 4 (Challengers) consists exclusively of men, or that Green Protectionists are represented by people under $30 \mathrm{yr}$, may be of interest to scientists from other disciplines (e.g. psychologists) to explore, but it should be kept in mind that our observations cannot be scaled up or applied to other cases.

\section{Analysing group attitudes}

The findings indicate commonalities in the attitudes of Conservationists (Group 1) and Green Protectionists (Group 5), with a factor correlation of 0.37 . Both groups 'support woodland expansion in treeline areas for multiple purposes' $(+1,+2$, respectively) and both reject the 'felling of trees in treeline areas, if the land is needed for other purposes' $(-3,-4)$. Alongside a number of commonalities (largely illustrated in Fig. 2), there are attitudinal differences between the 2 groups, a principal one being the statement that 'forest where trees are planted very close together is unacceptable for wildlife and should be cut down' $(-2,+4)$ (Tables 1 \& 5).

There are also certain commonalities between the perceptions of Productivists (Group 2) and NonGreen Technocrats (Group 3), with examples seen in Fig. 2. These commonalities, among others, concern the statements on 'planting of forests to produce timber as a policy priority' $(+3,+2)$ and that woodland expansion 'to create jobs is more important than protecting nature' $(+3,+2)$. Examples of differing perceptions include the statements that 'letting wildlife take care of itself should be a principle of forest management' $(+2,-1)$ (Fig. 2, Table 3) and 'forest management should be profitable and financially viable' $(+2,0)$ (Table 2).

Finally Group 4, labelled as Challengers, contests the opinions of the 4 other groups and strives for an ideal win-win position, where 'planting forests to produce timber is a policy priority' $(+4)$, but 'the rights of people to enjoy the beauty of treeline areas are recognized to be more important than making profits from the land' (+3) (Fig. 3, Table 4). These respondents try to find the middle ground and to somehow balance different priorities of the multipurpose forestry.

On the whole, the results provide an indication that key areas of potential conflict concerning ecosystembased adaptation of forest management practices in the upland woodlands of the Ukrainian Carpathians (as seen through the eyes of our respondents) encompass (1) expansion of woodlands for multiple purposes, (2) tree planting to produce timber as a policy priority, (3) rights of people to enjoy the beauty of landscapes as a more important objective than making profits from the land, (4) letting wildlife take care of itself and (5) shortage of investments as the main challenge in upland areas.

\section{DISCUSSION AND CONCLUSIONS}

Numerous studies on public attitudes towards forestry have been carried out worldwide (Jacobsen \& Koch 1995, Jensen \& Koch 2000, Karjalainen \& Tyrvainen 2002, Forestry Commission 2003). These studies either examined or generalized existing attitudes. Sometimes, they categorized them. However, rarely (Nijnik et al. 2013) - and never for the Ukrainian Carpathians-has scientific research managed to explain attitudinal diversity from the standpoints of people being observed. The questions of why stakeholders think the way they do, and what stakeholders perceive in their understanding of the interactions between manifold socio-economic and nature protection activities in upland woodlands that are managed for multiple purposes, have largely remained out of focus (Nijnik et al. 2010). Our research seeks to fill the existing knowledge gap. Stakeholder engagement in consultation processes and the uncovering of perceptions concerning multi-functional forestry development in the Ukrainian Carpathians provides an indication of social choices in support of the decisionmaking.

Co-constructing knowledge with various stakeholders, including local communities, and respecting their conventional culture and traditional ways of life, are essential requisites for the success of decision-making processes in uplands (Sarkki et al. 2016). Owing to the 'path-dependency' legacy (Nijnik \& Oskam 2004), this observation particularly applies to the Carpathian Mountains, where the development of tailor-made solutions and more active participation of stakeholders in decisionmaking processes is crucial (Bizikova et al. 2012).

Therefore, our methodological approach went beyond a traditional analysis of public attitudes, as it aimed to identify and explain a variety of factors influencing the decision-making processes. Through this study, our consultation and communication with stakeholders belonging to the Carpathian Mountains can be seen as a first step in promoting their engage- 

in treeline areas to create jobs is more important than protecting nature $(-3-2)$

Planting forests to produce timber should be a policy priority $(-2-3)$
The rights of people to enjoy the beauty of treeline areas are more important than making profits from the land $(+2+1)$

\section{Conversationists} Green Protectionists

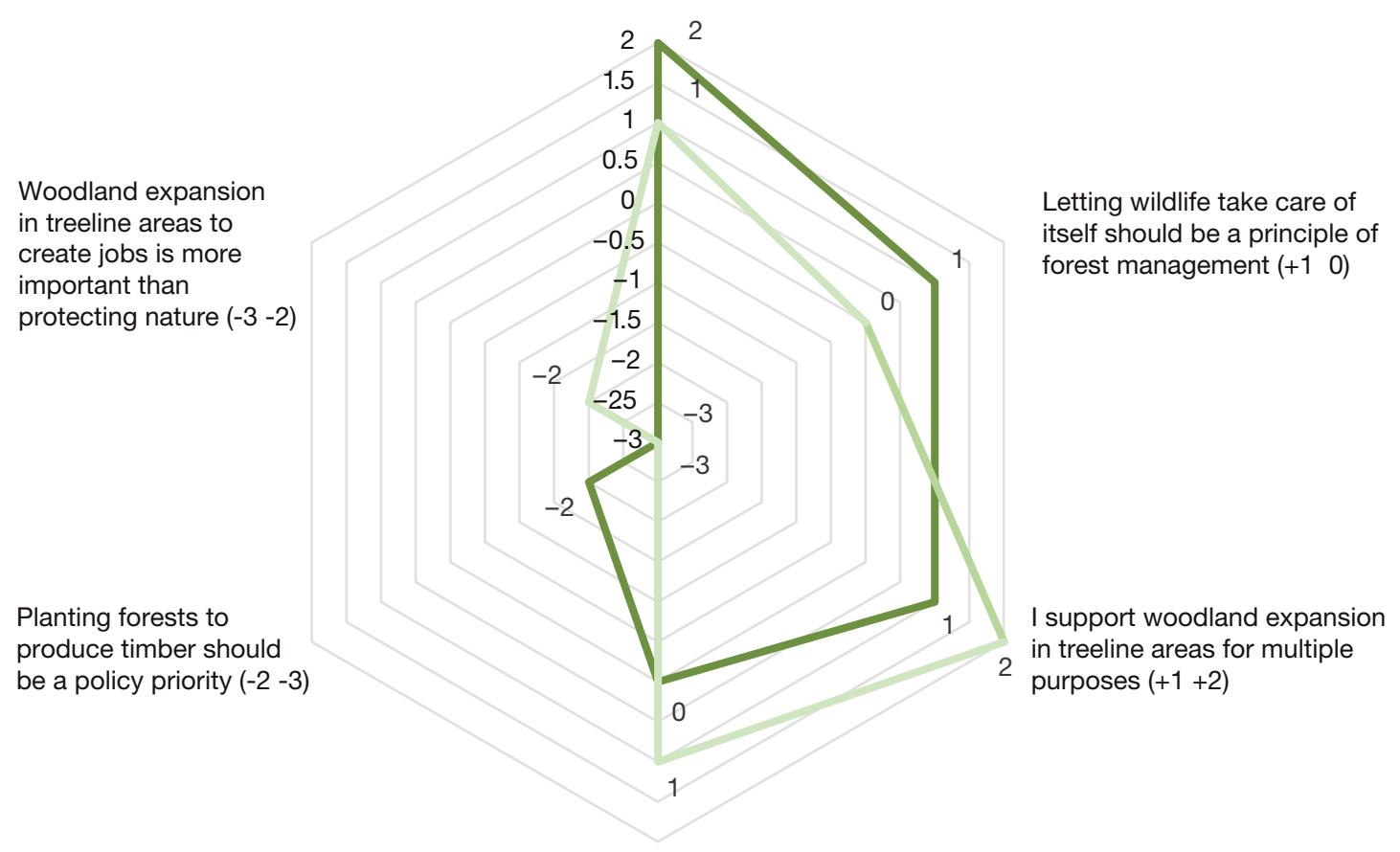

Shortage of investment is

the main challenge in treeline areas $(0+1)$

Woodland expansion in treeline areas to create jobs is more important than protecting nature $(+3+2)$

Planting forests to produce timber should be a policy priority $(+3+2)$
The rights of people to enjoy the beauty of treeline areas are more important than making profits from the land (-2 -4)

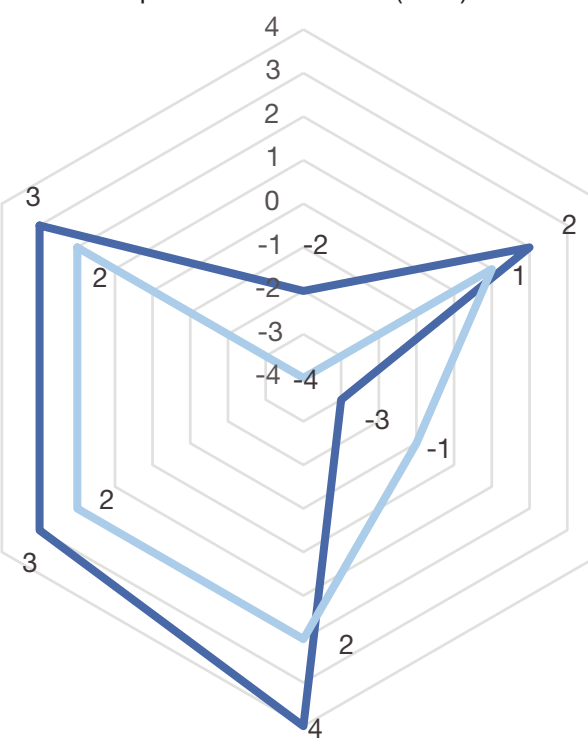

Shortage of investment is the main challenge in treeline areas $(+4+2)$
Letting wildlife take care of itself should be a principle of forest management $(+2+1)$
I support woodland expansion in treeline areas for multiple purposes $(-3-1)$

Fig. 2. Attitudinal commonalities and differences between Conservationists (Group 1) and Green Protectionists (Group 5); and between Productivists (Group 2) and Non-Green Technocrats (Group 3) 


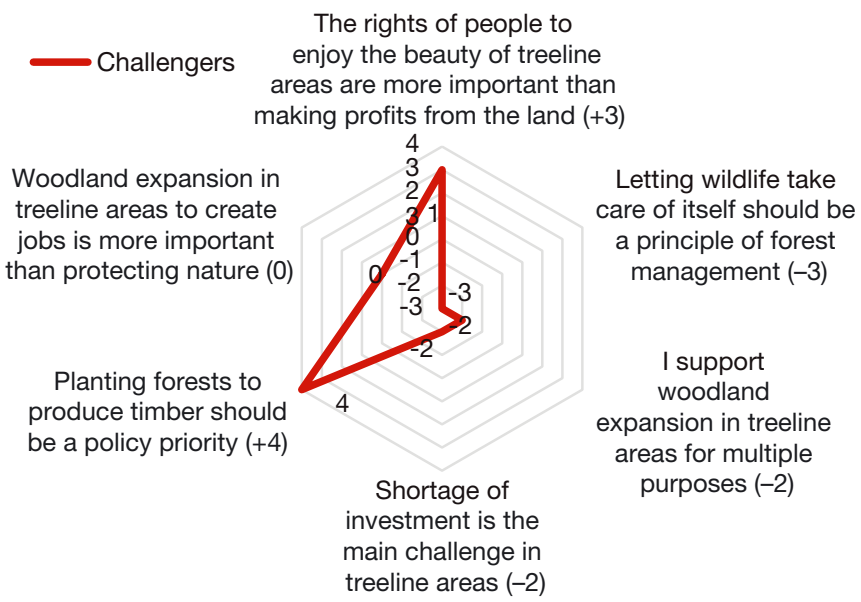

Fig. 3. Attitudinal diversity of Challengers (Group 4)

ment. The approach was beneficial both for the researchers and those participating in discussions, and indirectly for local communities. The method explained in this paper could potentially be useful elsewhere, allowing for mutual learning and capacity building, while key results from such studies could help to provide relevant policy actors and practitioners with some guidance for strategic planning and a more sustainable development of mountain areas.

Our approach, however, focused on perception analyses. It provided a discursive evaluation of major issues that respondents expressed. Although the identified and explained typologies likely reflect the attitudinal diversity of people beyond the respondent groups, the current research is not a general public. Other methods can be used (and be combined with the Q-method) for finding out how many people (within the 'stakeholder population' or for the public in general) have one opinion or another about multifunctional changes in upland woodlands.

Research findings suggest that people in the Ukrainian Carpathians feel attachment to woodlands and pay attention to biodiversity conservation and nature preservation. This is likely because woodlands are embedded in the local culture, and because people want to maintain their national heritage (Zahvoyska et al. 2014). Moreover, local stakeholders clearly benefit from woodlands beyond just using their cultural, supporting and regulatory services. The provisioning services of trees are considered to be important, e.g. the use of non-wood forest products and fire wood. This is likely because practically all forests in the region remain publicly owned and state managed (Soloviy 2010).

The results provided an understanding of the differences and similarities in the dominant attitudes of upland area stakeholders (those who are residing and working in the Ukrainian Carpathians). Acknowledging the different stakeholder reasonings was a stride towards making science that is more relevant to society. It was also a step towards gaining access to a 'real world' understanding of problems pertaining to forestry in the Carpathian uplands (through the eyes of people on the ground) and finding potential solutions to these problems (e.g. to avoid and manage possible conflicts).

In this regard, our findings concerning the differing (and at times conflicting) stakeholder attitudes towards woodland expansion, timber production, the importance for people to enjoy landscapes, wildlife conversation and investment policy, identified across the 5 attitudinal factors, may offer useful insights to assist decision-makers in addressing the opinions of each attitudinal group on a case-by-case basis, and applying the most suitable solutions to problems where consensus can hardly be reached. However, the question of whose preferences are most important remains challenging.

Also, as research findings indicate that some key differences in perceptions are caused by value conflicts, a participatory decision-making process may help to raise awareness of such conflicts and indicate the way towards reaching consensus, where possible. Similarities in the attitudes identified across some of the attitudinal groups (as seen in Fig. 2) could be helpful for reaching consensus and, eventually, enabling science to assist decision-makers in making forest policy and management in the Capathian Mountains more socially acceptable, inclusive and robust.

The findings from this paper specifically identified the following: similarities in attitudes with regard to native woodland regeneration; heterogeneity of attitudes and, therefore, key areas of potential conflict between stakeholders concerning forest policy and management practices in the uplands; improved participation in decision-making as a key challenge in the region; and a requirement for sustainable provision of forest ecosystem services. The identified attitudinal similarities could be of help in designing policy measures and better targeting of forest policy and management decisions.

Key findings from an analysis of socio-economic characteristics of respondents across the identified attitudinal groups indicated, in this particular research, that Conservationists are primarily young people. This is likely because this category of stakeholders is more idealistic and not too concerned with the current economic situation in Ukraine, e.g. the short- 
age of investment in the forestry sector, which is negatively affecting the Carpathian region. Also, the observation that Challengers are primarily men leaves us with speculations that men, more often than women, are willing to balance various dimensions of sustainability in the multi-functional forestry development in this region.

To conclude, it can be argued that the applied approach offers a credible means of performing stakeholder evaluations relevant to forest policy and management. We should be careful, however, regarding any attempt to transfer benefits across case studies or to extrapolate them. The results of stakeholder evaluation derived from the Q-method application are very much case- and context-dependent. Therefore, we suggest complementing this research with analyses of other complex institutional matters in the region, such as social innovation (e.g. using social network analysis), common pool resource and tenure rights problems.

Acknowledgements. The article is based on work from COST Action ES1203 SENSFOR (www.cost.eu), coordinated by Prof. Kari Laine and Vice Chair, Prof. Oddvar Skre. We also thank the Scottish Government, who supported this research through their Rural Affairs and the Environment Strategic Research Programme and the European Commission for support provided to the project on Social Innovation in Marginalised Rural Areas (SIMRA). This project has received funding from the European Union's Horizon 2020 Research and Innovation Programme under Grant Agreement No. 677622. It is coordinated by the James Hutton Institute and includes the University of Oulu. We are also grateful to respondents who contributed to the survey, to suggestions by the Guest-Editor, Prof. Frans Wielgolaski, on an earlier draft, to our colleague from the James Hutton Institute, Ms Gillian Donaldson-Selby, for the English language proofreading of the manuscript and to the anonymous reviewers for their comments.

\section{LITERATURE CITED}

Barry J, Proops J (1999) Seeking sustainability discourses with Q methodology. Ecol Econ 28:337-345

Berkes F (2009) Evolution of co-management: role of knowledge generation, bridging organisations and social learnings. J Env Manage 90:1692-1702

Bizikova L, Nijnik M, Kluvanková-Oravská T (2012) Sustaining multifunctional forestry through the developing of social capital and promoting participation: a case of multiethnic mountain communities. Small-scale For 11: 301-319

Brown SR (1980) Political subjectivity. Applications of Q methodology in political science. Yale University Press, New Haven, CT

Brown S (1996) Q methodology and qualitative research. Qual Health Res 6:561-567

Davies BB, Sherlock K, Rauschmayer F (2005) 'Recruitment', 'composition' and 'mandate' issues in deliberative pro- cesses: should we focus on arguments rather than individuals? Environ Plan 23:599-615

Elbakidze M, Angelstam P (2013) Sustainable forest management from policy to landscape and back again: a case study in the Ukrainian Carpathians Mountains. In: Kozak J, Ostapowicz K, Bytnerowicz A, Wyzga B (eds) The Carpathians: integrated nature and society towards sustainability. Springer-Verlag, Berlin

European Commission (2015) Paris Agreement. Available at http://ec.europa.eu/clima/policies/international/negotiations/ paris_en (accessed on 1 December 2016)

Forestry Commission (2003) UK public opinion survey of forestry. Forestry Commission, Edinburgh

Funtowicz SO, Ravetz J (1993) Science for the postnormal age. Futures 25:739-755

Jacobsen CH, Koch NE (1995) Summary report on ongoing research on public perceptions and attitudes on forestry in Europe. Danish Forest and Landscape Research Institute, Horsholm

Jensen CH, Koch NE (2000) Measuring forest preferences of the population-a Danish approach. Schweiz Z Forstwesen 151:11-16

Karjalainen E, Tyrvainen L (2002) Visualization in forest landscape preference research: a Finnish perspective. Landsc Urban Plan 59:13-28

Keeton WS, Crow SM (2009) Sustainable forest management alternatives for the Carpathian Mountain region: providing a broad array of ecosystem service. In: Soloviy I, Keeton WS (eds) Ecological economics and sustainable forest management: developing a trans-disciplinary approach for the Carpathian Mountains. UNFU Press, Lviv, p 109-126

Krott M (2008) Forest government and forest governance within a Europe in change. In: Cesaro L, Gatto P, Pettenella D (eds) The multifunctional role of forests - policies, methods and case studies. EFI Proc. No. 55. Gummerus Printing, Saarijärvi, p 13-25

Krynytskyy GT, Chernyavskyy MV (eds) (2014) Close to nature and multifunctional forest management in the Carpathian region of Ukraine and Slovakia. PE "Circle", Uzhorod

McKeown B, Thomas B (2013) Q methodology. Sage Publications, Thousand Oaks, CA

Miller DR, Vogt N, Nijnik M, Brondizio E, Fiorini S (2009) Integrating analytical and participatory techniques for planning the sustainable use of land resources and landscapes. In: Geerteman S, Stillwell J (eds) Plan support systems: best practice and new methods. Springer, Dordrecht

*Muñoz-Rojas J, Nijnik M, Puente MG, Garcia FC (2015) Synergies and conflicts in the use of policy and planning instruments for implementing forest and woodland corridors and networks in Scotland. For Policy Econ 57:47-64

Nijnik M, Miller D (2014) Targeting sustainable provision of forest ecosystem services with special focus on carbon sequestration. In: Matyssek $R$, Clarke $N$, Cudlín $P$, Mikkelsen T, Tuovinen JP, Wiesser G, Paoletti E (eds): Climate change, air pollution and global challenges: understanding and perspectives from forest research. Elsevier, Oxford, p 547-565

Nijnik M, Oskam A (2004) Governance in Ukrainian forestry: trends, impacts and remedies. Int J Agric Resour Gov Ecol 3:116-133

Nijnik A, Nijnik M, Soloviy I (2009a) Challenges and opportunities for sustainable development in the Ukrainian 
Carpathians. MRI Newsl 2:21-24

Nijnik M, Soloviy I, Nijnik A, Deyneka A (2009b) Challengers and potential policy responses towards sustainable mountain development and nature conservation in the Ukrainian Carpathians. In: Chmielewski T (ed) Nature conservation management: from idea to practical result. AlterNet, Lublin, p 132-149

Nijnik M, Nijnik A, Lundin L, Staszewski T, Postolache C (2010) Stakeholder attitudes to multi-functional forests in Europe. For Trees Livelihoods 19:341-358

Nijnik M, Miller D, Nijnik A (2013) Linking multi-functional forestry goals with sustainable development objectives: a multi-national study. J Settl Spat Plann 2:185-190

Nijnik M, Nijnik A, Bergsma E, Matthews R (2014) Heterogeneity of experts' opinion regarding opportunities and challenges of tackling deforestation in the tropics. Mitig Adapt Strategies Glob Change 19:621-640

Nijnik M, Nijnik A, Brown I (2016) Exploring the linkages between multi-functional forestry goals and the legacy of spruce plantations in Scotland. Can J For Res 46: 1247-1254

* Prell C, Hubacek K, Reed M (2009) Stakeholder analysis and social network analysis in natural resource management. Soc Nat Resour 22:501-518

Sarkki S, Karjalainen TP (2012) Science and issue advocacy in a forestry debate in northern Finland. Polar $\mathrm{J} 2$ : $125-138$

Sarkki S, Ficko A, Grunewald K, Nijnik M (2016) Benefits from and threats to European treeline ecosystem services: an exploratory study of stakeholders and governance. Reg Environ Change 16:2019-2032

Schmolck P (2012) PQMethod version 2.33. Available at http://schmolck.userweb.mwn.de/qmethod/

Soloviy IP (2010) Policy for forest sector sustainable development: paradigm and instruments. Ukrainian National Forestry University Press, Lviv

Editorial responsibility: Nils Chr. Stenseth, Oslo, Norway
Soloviy I, Nijnik M, Ilkiv K (2012) Mountain forestry policy and strategies in response to climate change challenges. $\mathrm{J}$ Ecol Econ 111-120

Stephenson W (1963) Independency and operationizm in Qsorting. Psychol Rec 13:269-272

* Stevenson H (2015) Contemporary discourses of green political economy: a Q method analysis. J Env Policy Plan. http://dx.doi.org/10.1080/1523908 X.2015.1118681

The Carpathian Convention (2003) www.carpathianconvention.org/documents-carpathian-convention.html (accessed on 7 December 2015), UNEP, Vienna

The Forest Code of Ukraine (2006) http://zakon.rada. gov.ua/cgi-bin/laws/anot.cgi?nreg=3852-12 Verkhovna Rada, Kyiv (accessed on 7 December 2015)

van Asselt MBA, Mellors J, Rijkens-Klomp N, Greeuw SCH, Molendijk KGP, Beers PJ, van Notten P (2001) Building blocks for participation in integrated assessment: a review of participatory methods. International Centre for Integrated Studies, Maastricht

van Exel J, De Graaf G (2005) Q methodology: a sneak preview. Erasmus University, Rotterdam

Vogel J, Lowham E (2007) Building consensus for constructive action: a study of perspectives on natural resource management. J For 105:20-27

Watts S, Stenner P (2012) Doing Q methodological research: theory, method and interpretation. Sage, London

Zahvoyska L, Sarkki S, Zhyla T (2014) Perceptions of treeline ecosystem services and their governance: focus on Ukrainian Carpathians. In: Kruhlov I, Prots B (eds) Local responses to global challenges. Proc. Forum Carpaticum, Sept 16-19, 2014. Ukrainian Bestseller, Lviv, p 65-69

Zahvoyska L, Nijnik M, Sarkki S, Nijnik A, Pelyuch O (2015) Insights into treeline ecosystem services of the Ukrainian Carpathians from a stakeholder's perspective: an analysis of challenges for adaptive governance. J Proc For Acad Sci Ukr: Coll Sci Pap 13:193-200

Submitted: April 8, 2016; Accepted: December 6, 2016 Proofs received from author(s): March 14, 2017 